\title{
Nuclear and Plastid DNA Sequence-based Molecular Phylogeography of Salvadora oleoides (Salvadoraceae) in Punjab, India Reveals Allopatric Speciation in Anthropogenic Islands Due to Agricultural Expansion
}

\section{Felix Bast ${ }^{*}$ and Navreet Kaur}

Centre for Plant Sciences, Central University of Punjab, Bathinda, Punjab, 151001, India

*Corresponding author: Bast F, Centre for Plant Sciences, Central University of Punjab, Bathinda, Punjab, 151001, India, Tel: +91 98721 52694; Fax: 713-500-5495; Email: felix.bast@gmail.com

Receiving date: May 25, 2017; Acceptance date: June 15, 2017; Publication date: June 26, 2017

Copyright: ( 2017 Bast F, et al. This is an open-access article distributed under the terms of the Creative Commons Attribution License, which permits unrestricted use, distribution, and reproduction in any medium, provided the original author and source are credited.

\begin{abstract}
Salvadora oleiodes is a tropical tree species belonging to the little-known family Salvadoraceae and distributed in the arid regions of Africa and Asia. Aims of our study were to trace the microevolutionary legacy of this tree species with the help of sequence-based multi-local phylogeography and to find the comparative placement of family Salvadoraceae within angiosperm clade malvids. A total 20 geographical isolates were collected from different regions of North India, covering a major part of its species range within the Indian Subcontinent. Sequence data from nuclear-encoded Internal Transcribed Spacer region (ITS1-5.8S-ITS2) and plastid-encoded trnL- $F$ spacer region, were generated for this species for the first time in the world. ITS-based Bayesian phylogeographic analysis revealed the existence of four clades while trnL-F spacer based Bayesian analysis revealed one clade for this species distributed in the Indian subcontinent. Between these two loci, ITS revealed more distinct phylogeographic clades, indicating the phylogeographic utility of this locus for the systematics of Salvadoraceae. Interestingly, the ITS phylogeny indicated the existence of allopatric speciation in this tree species. Factors such as habitat destruction through agricultural expansion of plains might have forced the remaining population of this threatened tree species to isolated patches of thorn forest biotas, the 'anthropogenic islands', analogous to an archipelago. Phylogenetic analyzes based on trnL-F spacer suggested a synonymy of this species with Salvadora angustifolia. Maximum Likelihood gene tree based on ITS sequence data revealed that Salvadoraceae belongs to Sapindales rather than Brassicales. However, in the gene tree based on $\operatorname{trn} L-F$ spacer sequence, this family clustered within Brassicales. An evolutionary congruence of $S$. oleoides isolates across its range in North India is revealed in this study. Given the conflicting results on the relative placement of Salvadoraceae in Brassicales and Sapindales, the need for further phylogenetic analyses of malvids using supermatrix approach is highlighted.
\end{abstract}

Keywords: Brassicales; Conservation genetics; Molecular systematics; Phylogenetics; Rosids; Sapindales

\section{Introduction}

Salvadora oleoides Decne is a tropical tree-shrub species belong to the little-known family Salvadoraceae Lindl. This tree species has opposite individual undivided leaves, imbricated corolla lobes, tetramerous flowers with four stamens, and basally-fused connate petals. Although the natural range of this species extends from subSaharan Africa up to the island of Java, Indonesia, this species is under the stress of habitat destruction due to widespread deforestation and over-exploitation. Natural habitats of this tree, tropical thorn forests, are endangered by a variety of human activities, especially expansion of agricultural fields. While neither the official IUCN Red List, nor the recent estimate of threatened tree species worldwide [1] ascertain the conservation status of $S$. oleoides, there are some indications that this species is threatened [2]. In India, the tree is found in the isolated thorn forests of the arid regions of North India, especially in and around the Thar Desert.

As per the latest APG III system, the family Salvadoraceae is recognized in cabbage order Brassicales [3]. This family consists of poorly understood genera Salvadora, Azima, and Dobera. Similar to the other members of Brassicales, members of Salvadoraceae produces a pungent phytochemical, mustard oil glucosinolate. Production of this chemical is thought to be a synapomorphic character of the entire crown group of Brassicales [4]. Since time immemorial plants of genus Salvadora had been used in traditional Ayurvedic medicine for a wide variety of purported health benefits; including hypoglycemic and hypolipidemic [5], antimicrobial [6] and as an antibacterial toothbrush. A recent analysis of the feces of a critically endangered Lemur species endemic to Madagascar, golden-crowned Sifaka (Propithecus tattersale), revealed that a major portion of its diet was encompassed of the leaves of Salvadora angustifolia [7], exposing a small facet of its hidden ecological importance.

Despite its ecological, conservational and commercial importance, systematics and taxonomy of this tropical tree species have neither been analyzed using molecular systematics, nor its evolutionary legacy been traced using sequence-based phylogenetic approach. For example, the phylogenetic position of $S$. oleoides within higher taxonomic hierarchies, such as Brassicales, malvids or rosids, had never been assessed to date. Prior to this study, no nucleotide sequence data had been available for this species in the GenBank database. Till date, there are only two reports available that analyzed relative position of genus Salvadora within malvids. The first study was based on chloroplast encoded $r b c L$ gene and nuclear-encoded $18 \mathrm{~S}$ sequences, and the study revealed phylogenetic affinity of this genus with Brassicales/Capparales [4]. The second study was based on $r b c L$ gene 
Citation: Bast F, Kaur N (2017) Nuclear and Plastid DNA Sequence-based Molecular Phylogeography of Salvadora oleoides (Salvadoraceae) in Punjab, India Reveals Allopatric Speciation in Anthropogenic Islands Due to Agricultural Expansion. J Phylogenetics Evol Biol 5: 180. doi:10.4172/2329-9002.1000180

Page 2 of 7

and that too corroborated phylogenetic affinity of genus Salvadora within Brasicales [8]. Genetic heterogeneity of $S$. oleoides from India had previously been assessed by RAPD method and concluded a very high genetic heterogeneity, with percent polymorphism at 90.09\% [9]. Isozyme electrophoresis-based analysis also revealed a high genetic variation $(\mathrm{HT}=0.249)$ for this species distributed in North India [10].

Primary objective of this study was to assess the number, phylogenetic relationships and geographic distributions of evolutionary lineages of $S$. oleoides in North India- a first such phylogeographic assessment of a member of family Salvadoraceae throughout the world. We were especially motivated by the pithy dictum famously declared by Croizat [11], that the earth and life are co-evolving. Given that the natural range of this species in Indian Subcontinent lies along the North-Western fringe of Indian tectonic plate, we were interested whether biogeographic processes akin to the Gondwanaland and Indian plate contributed in the distribution of this species. For example, species-range expansion through geodispersion phenomena during immediate aftermath of the collision of Indian plate to the Eurasian plate in Eocene epoch of Cenozoic around 50 million years ago [12], or vicariance events happened subsequently after the formation of the Himalayas, might have shaped the current patterns of the distribution of genetic diversity and population differentiation within species. Brassicales are believed to have originated either in Turkey or Irano-Turanian region and diversified 85 million years ago, prior to the collision of the Indian plate to the Eurasian Plate [13]. Given that conservation status of $S$. oleoides is much contested amidst recommendations to classify it as a threatened species [14], a high-resolution assessment of genetic variation using DNA barcoding will be of paramount importance in its conservation genetics scenario as well. This is because extent and distribution of intraspecific variation is a reliable proxy for determining evolutionary potential and long-term survival of tree species [15]. Our second objective had been to resolve the phylogenetic placement of this species and family Salvadoraceae within malvids. In many schemes of phylogenetic systematics Salvadoraceae had been considered as part of orders Brassicales/Capparales [3], Sapindales [16], Salvadorales [17], Oleales [18], Celastrales [19] and even as an "outsider", incerta sedis [20]. As nucleo-ribosomal Internal Transcribed Spacers 1 and 2 are the most widely covered DNA barcode for angiosperms at the NCBI GenBank [21] and as sequence information at this locus is not yet available for Salvadoraceae, we were interested to generate ITS sequence data and test various phylogenetic hypotheses on the placement of this family within malvids. In addition to ITS, we also employed plastid-encoded $t r n L-F$ spacer region, as no DNA sequence data at this locus is available for $S$. oleoides at GenBank. $\operatorname{trn} L-F$ spacer region is also routinely employed for phylogenetic and phylogeographic studies of angiosperms.

\section{Materials and Methods}

\section{Taxon sampling}

Young leaves were collected from 20 geographic isolates of Salvadora oleoides covering the greater part of its range in the Indian subcontinent (Table 1 and Figure 1). Leaf samples from three individual trees from each location were separately analyzed, including PCR and sequencing at two loci, for intra-population heterogeneity. No special permission was required to collect these plant materials, as none of the sampling locations were part of the areas designated as protected by Government of Punjab. Collected specimens were transported to the laboratory in zip-lock polythene bags. Pressed vouchers were prepared and deposited in the Central National Herbarium, Botanical Survey of India, and Calcutta (Index Herbariorum Code: CAL). Samples for molecular analysis were stored at $-80^{\circ} \mathrm{C}$ till further analysis.

\begin{tabular}{|c|c|c|c|c|c|c|c|}
\hline Voucher No. & Location & Collected by & Collection date & Latitude (N) & Longitude (E) & $\begin{array}{l}\text { ITS1-5.8S- } \\
\text { ITS2 } \\
\text { sequence } \\
\text { generated } \\
\text { (GenBank } \\
\text { Accession) }\end{array}$ & $\begin{array}{l}\text { trnL-F } \\
\text { spacer } \\
\text { sequence } \\
\text { generated } \\
\text { (GenBank } \\
\text { Accession) }\end{array}$ \\
\hline CUP VOUCHER-SO-2014-1 & Faridkot & $\begin{array}{l}\text { Sukhwant Singh and } \\
\text { Navreet Kaur }\end{array}$ & $27-02-2014$ & $30^{\circ} 38^{\prime} 05.62^{\prime \prime} \mathrm{N}$ & $74^{\circ} 47^{\prime} 28.10^{\prime \prime} \mathrm{E}$ & KP795947 & KP795970 \\
\hline CUP VOUCHER-SO-2014-2 & Sangrur & $\begin{array}{l}\text { Sukhwant Singh and } \\
\text { Navreet Kaur }\end{array}$ & 02-03-2014 & $30^{\circ} 15^{\prime} 22.61^{\prime \prime} \mathrm{N}$ & $75^{\circ} 44^{\prime} 42.88^{\prime \prime} \mathrm{E}$ & KP795949 & KP795958 \\
\hline CUP VOUCHER-SO-2014-3 & Mansa & $\begin{array}{l}\text { Sukhwant Singh and } \\
\text { Navreet Kaur }\end{array}$ & 07-03-2014 & $30^{\circ} 06^{\prime} 18.20^{\prime \prime} \mathrm{N}$ & $75^{\circ} 10^{\prime} 39.55^{\prime \prime} \mathrm{E}$ & - & KP795969 \\
\hline CUP VOUCHER-SO-2014-4 & $\begin{array}{l}\text { Talwandi } \\
\text { Sabo }\end{array}$ & $\begin{array}{l}\text { Sukhwant Singh and } \\
\text { Navreet Kaur }\end{array}$ & 07-03-2014 & $29^{\circ} 59^{\prime} 48.65^{\prime \prime} \mathrm{N}$ & $75^{\circ} 09^{\prime} 32.08^{\prime \prime} \mathrm{E}$ & KP795946 & KP795965 \\
\hline CUP VOUCHER-SO-2014-5 & Barnala & $\begin{array}{l}\text { Sukhwant Singh and } \\
\text { Navreet Kaur }\end{array}$ & 08-03-2014 & $30^{\circ} 19^{\prime} 35.18^{\prime \prime} \mathrm{N}$ & $75^{\circ} 30^{\prime} 10.70^{\prime \prime} \mathrm{E}$ & KP795950 & KP795968 \\
\hline CUP VOUCHER-SO-2014-6 & Patiala & $\begin{array}{l}\text { Sukhwant Singh and } \\
\text { Navreet Kaur }\end{array}$ & 08-03-2014 & $30^{\circ} 16^{\prime} 24.70^{\prime \prime} \mathrm{N}$ & $75^{\circ} 58^{\prime} 35.37^{\prime \prime} \mathrm{E}$ & - & KP795964 \\
\hline CUP VOUCHER-SO-2014-7 & Taran Taran & Gurbeer Singh & $15-03-2014$ & $31^{\circ} 10^{\prime} 46.35^{\prime \prime} \mathrm{N}$ & $74^{\circ} 54^{\prime} 12.08^{\prime \prime} \mathrm{E}$ & - & KP795962 \\
\hline CUP VOUCHER-SO-2014-8 & Malaut & Jasdeep Singh & $18-03-2014$ & $30^{\circ} 11^{\prime} 36.31^{\prime \prime} \mathrm{N}$ & $74^{\circ} 24^{\prime} 33.11^{\prime \prime} \mathrm{E}$ & - & KP795961 \\
\hline CUP VOUCHER-SO-2014-9 & Moga & Sukhwant Singh & 02-04-2014 & $30^{\circ} 43^{\prime} 10.13^{\prime \prime} \mathrm{N}$ & $75^{\circ} 06^{\prime} 02.04^{\prime \prime} \mathrm{E}$ & - & KP795960 \\
\hline CUP VOUCHER-SO-2014-10 & Hoshiarpur & Gurpreet Singh & 03-04-2014 & $31^{\circ} 38^{\prime} 08.66^{\prime \prime} \mathrm{N}$ & $75^{\circ} 50^{\prime} 14.66 \prime \mathrm{E}$ & - & - \\
\hline
\end{tabular}


Citation: Bast F, Kaur N (2017) Nuclear and Plastid DNA Sequence-based Molecular Phylogeography of Salvadora oleoides (Salvadoraceae) in Punjab, India Reveals Allopatric Speciation in Anthropogenic Islands Due to Agricultural Expansion. J Phylogenetics Evol Biol 5: 180. doi:10.4172/2329-9002.1000180

Page 3 of 7

\begin{tabular}{|c|c|c|c|c|c|c|c|}
\hline CUP VOUCHER-SO-2014-11 & Ferozpur & $\begin{array}{l}\text { Sukhwant Singh and } \\
\text { Navreet Kaur }\end{array}$ & 04-04-2014 & $30^{\circ} 53^{\prime} 38.79^{\prime \prime} \mathrm{N}$ & $74^{\circ} 56^{\prime} 23.46^{\prime \prime} \mathrm{E}$ & - & KP795967 \\
\hline CUP VOUCHER-SO-2014-12 & Amritsar & Sukhwant Singh & 07-04-2014 & $31^{\circ} 38^{\prime} 09.89^{\prime \prime} \mathrm{N}$ & $74^{\circ} 49^{\prime} 27.79$ "E & - & - \\
\hline CUP VOUCHER-SO-2014-13 & Zira & $\begin{array}{l}\text { Sukhwant Singh and } \\
\text { Navreet Kaur }\end{array}$ & 09-04-2014 & $30^{\circ} 52^{\prime} 43.38^{\prime \prime} \mathrm{N}$ & $74^{\circ} 59^{\prime} 16.70$ "E & KP795951 & KP795963 \\
\hline CUP VOUCHER-SO-2014-14 & Kotkapura & $\begin{array}{l}\text { Sukhwant Singh and } \\
\text { Navreet Kaur }\end{array}$ & $09-05-2014$ & $30^{\circ} 38^{\prime} 20.34^{\prime \prime} \mathrm{N}$ & $74^{\circ} 49^{\prime} 46.35^{\prime \prime} \mathrm{E}$ & KP795955 & - \\
\hline CUP VOUCHER-SO-2014-15 & Bathinda & Navreet Kaur & 21-05-2014 & $30^{\circ} 11^{\prime} 45.09^{\prime \prime} \mathrm{N}$ & $74^{\circ} 56^{\prime} 42.99^{\prime \prime} \mathrm{E}$ & KP795948 & KP795957 \\
\hline CUP VOUCHER-SO-2014-16 & Chandigarh & $\begin{array}{l}\text { Sukhwant Singh and } \\
\text { Navreet Kaur }\end{array}$ & $22-05-2014$ & $30^{\circ} 46^{\prime} 37.19^{\prime \prime} \mathrm{N}$ & $76^{\circ} 45^{\prime} 34.70$ ”E & - & - \\
\hline CUP VOUCHER-SO-2014-17 & Jalandhar & $\begin{array}{l}\text { Sukhwant Singh and } \\
\text { Sukhdeep Kaur }\end{array}$ & 03-06-2014 & $31^{\circ} 07^{\prime} 91.78^{\prime \prime} \mathrm{N}$ & $75^{\circ} 33^{\prime} 57.29$ ” E & KP795952 & - \\
\hline CUP VOUCHER-SO-2014-18 & Ludhiana & Sukhwant Singh & 06-06-2014 & $30^{\circ} 67^{\prime} 49.13^{\prime \prime} \mathrm{N}$ & $75^{\circ} 45^{\prime} 74.08^{\prime \prime} \mathrm{E}$ & KP795956 & - \\
\hline CUP VOUCHER-SO-2014-19 & Abohar & Harjoban Singh & $12-06-2014$ & $30^{\circ} 04^{\prime} 09.80^{\prime \prime} \mathrm{N}$ & $74^{\circ} 19^{\prime} 21.23^{\prime \prime} \mathrm{E}$ & KP795953 & KP795966 \\
\hline CUP VOUCHER-SO-2014-20 & Muktsar & Harpreet Singh & $13-06-2014$ & $30^{\circ} 40^{\prime} 89.56^{\prime \prime} \mathrm{N}$ & $74^{\circ} 52^{\prime} 20.13^{\prime \prime} \mathrm{E}$ & KP795954 & KP795959 \\
\hline
\end{tabular}

Table 1: Details of geographical isolates analyzed in this study. A dash (-) indicate no data available.

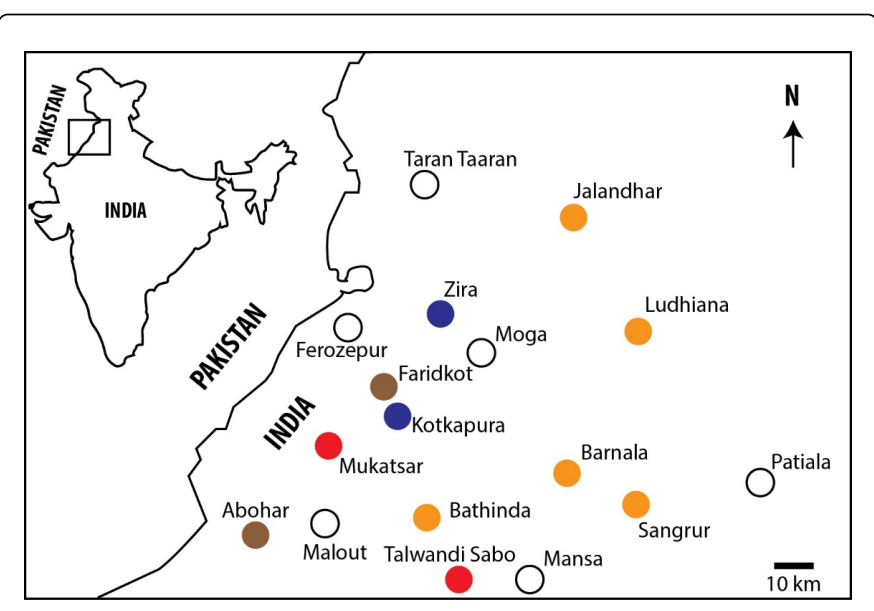

Figure 1: Map indicating sampling locations. ITS haplotypes shown in Figure 2 are represented in colored icons. Red=Clade 1; Blue=Clade 2; Brown=clade 3; and Dark Brown=Clade 4. Empty circles represent other locations included in the present study. Zoomed location in Indian map is highlighted in Inset.

\section{DNA extraction and PCR amplification}

Total genomic DNA was extracted from the specimens using $\mathrm{Hi}$ PurATM Plant Genomic Extraction Kit (Hi Media Laboratories Pvt. Ltd., Mumbai) following manufacturer's protocol. The quality of DNA was checked on $0.8 \%$ agarose gel, and the quantity of DNA was determined with a spectrophotometer (NanoDrop2000, Thermo Scientific). Extracted DNA was stored at $-20^{\circ} \mathrm{C}$. For PCR amplification, $20 \mu \mathrm{l}$ reaction mixture was prepared containing $2 \mu \mathrm{l}$ of 10X reaction buffer with $1.8 \mu \mathrm{l} 3 \mathrm{mM}$ magnesium chloride (Applied Biosystems, Foster City, CA, USA), $4 \mu$ each of $10 \mu \mathrm{m}$ primers: ITS1 (5' TCCGTAGGTGAACCTGCGG 3') [22], ITS4 (5' TCCTCCGCTTATTGATATGC 3') [22], $\operatorname{trnL-F} \quad\left(5^{\prime}\right.$ CGAAATCGGTAGACGCTACG 3') [23], $\operatorname{trn} L-R \quad\left(5^{\prime}\right.$
ATTTGAACTGGTGACACGAG 3') [24], $2 \mu \mathrm{l}$ of $10 \mu \mathrm{m}$ dNTP mixture containing dATP, dTTP, dCTP and dGTP (Genaxy Scientific, India), $0.2 \mu \mathrm{l}$ of $5 \mathrm{u} / 500 \mu \mathrm{l}$ Taq DNA Polymerase (Thermo Scientific, India), 4 $\mu \mathrm{l}$ of template DNA and $2 \mu \mathrm{l}$ sterile water. PCR amplification were carried out in a programmable thermal cycler (Bio-Rad, India) and reaction profile included an initial denaturation at $94^{\circ} \mathrm{C}$ for $5 \mathrm{~min}$, followed by 35 cycles of $94^{\circ} \mathrm{C}$ for $1 \mathrm{~min}, 52^{\circ} \mathrm{C}$ for $2 \mathrm{~min}$ and $72^{\circ} \mathrm{C}$ for 2 min and a final extension of $72^{\circ} \mathrm{C}$ for $10 \mathrm{~min}$. Amplified products were electrophoresed on 1.5\% agarose gel for $25 \mathrm{~min}$ at $250 \mathrm{~V}$ and visualized with ethidium bromide in order to determine approximate length and purity.

\section{Purification of PCR product and DNA sequencing}

Positive reactions were purified using Exo SAP-IT PCR clean-up kit following manufacturer's instructions (USB Corporation, Cleveland, $\mathrm{OH}$, USA). The purified PCR products were subjected to chain termination reaction with the following composition of reaction mixture-buffer $2 \mu \mathrm{l}$, sequence-ready reaction mixture $1 \mu \mathrm{l}$, primer $2 \mu \mathrm{l}$, PCR product $2 \mu \mathrm{l}$ and autoclaved distilled water $3 \mu \mathrm{l}$. The PCR conditions for chain termination reaction were as follows $-95^{\circ} \mathrm{C}$ for 5 min, followed by 50 cycles of denaturation at $95^{\circ} \mathrm{C}$ for $45 \mathrm{~s}$, annealing at $52^{\circ} \mathrm{C}$ for $30 \mathrm{~s}$ and extension at $60^{\circ} \mathrm{C}$ for $4 \mathrm{~min}$. For cleaning of sequencing reaction, Big-Dye $\mathrm{X}$ terminator kit (Applied Biosystems, Foster City, CA, USA) was used, following manufacturer's protocol. Purified PCR products were subjected to bidirectional Sanger sequencing using a dideoxy chain termination protocol with ABI BigDye Terminator Cycle Sequencing Ready Reaction Kit v3.1 (Applied Biosystems, Foster City, CA, USA) and a programmable thermal cycler (Veriti, ABI, USA), as per [25]. DNA sequences were assembled using the computer program CodonCodeAligner (CodonCode Corporation, USA). Out of 20 isolates, ITS1-5.8S-ITS2 locus from only 11 isolates got amplified and its sequence length ranged between 605-658 bp. TrnL-F spacer locus from 14 isolates got amplified and its sequence length ranged between $188-478 \mathrm{bp}$. Out of 75 generated sequences, only 25 were unique, as three individual trees at each of the sampling populations (geographical locations) had 
Citation: Bast F, Kaur N (2017) Nuclear and Plastid DNA Sequence-based Molecular Phylogeography of Salvadora oleoides (Salvadoraceae) in Punjab, India Reveals Allopatric Speciation in Anthropogenic Islands Due to Agricultural Expansion. J Phylogenetics Evol Biol 5: 180. doi:10.4172/2329-9002.1000180

Page 4 of 7

exactly same sequences for both of the genomic loci analyzed. Unique 25 sequences were deposited in Genbank (Table 1).

\section{Multiple Alignment and Phylogenetic Analyses}

Step-by-step protocol followed for contig assembly, multiple sequence alignment, ML ModelTest, and phylogenetic analyzes are available at Nature Protocols [26]. In summary, sequences were assembled using CodonCode Aligner, BLASTN sequence homology search, Multiple Sequence Alignments, consensus sequence generation, and Bayesian Inference (BI) phylogenetic inference (using MrBayes add-in) were conducted in Geneious Pro (Biomatters, NZ), and Model Selection, pairwise distance estimation, and Maximum Likelihood phylogenetic inference were conducted in MEGA. For intraspecific phylogeographic assessments, an accession of Khaya nyasica (Sapindales) was used as an outgroup for ITS dataset and an accession of Borthwickia trifoliata (Brassicales) for trnL-F spacer dataset. For phylogenetic assessment of malvids, we used accessions of Euphorbia spp. as outgroups, as in Rodman et al. [4]. The rationale for choosing these outgroups was to have taxa sufficiently closely related to the in-group for resolving phylogenetic structures to the maximum extent. For example, as Malvid gene tree based on ITS revealed a phylogenetic affinity of Salvadora to Sapindales, we used another member of Sapindales rather than Brassicales as an outgroup for intraspecific phylogeographic assessment of Salvadora oleoides. We have concurrently tested a number of different outgroup taxa, including as far as Ficus (Moraceae), but the topology of phylogram remained similar indicating the robustness of the method.

\section{Results}

\section{Intra-population heterogeneity}

Neither within-individual polymorphisms (dual-peaks at electropherograms/heterozygosity due to imperfect homogenization of multiple rRNA genes, paralogs, pseudo-genes, etc.) nor withinpopulation polymorphisms were observed at either of the two loci analyzed. Three sequences at each of the sampling populations had no nucleotide differences either at ITS1-5.8S-ITS2, or at $\operatorname{trnL}-F$ spacer region.

\section{BLASTN}

BLASTN Homology search with NCBI nr nucleotide database (word size=10, Max E-value =1e-1 and gap cost-open extend=5.2) revealed interesting results. ITS sequences, both individually, as well as the consensus sequences generated for 11 of our ingroup, isolates, retrieved Arfeuillea arborescens (EU720461) as the closest hit with an E-value of $3.24 \mathrm{e}-93$ and $79 \%$ identity. Particulars of top 10 hits are summarized in Table 2, and all 10 of them were from order Sapindales. This came as a surprise, as the current consensus among molecular phylogeneticists working on angiosperm systematics is that the family Salvadoraceae belongs to Brassicales. Top 100 results included orders as diverse as Fagales (Nothofagus) and Malpighiales (Quiina, Lacunaria) however not a single accession belonging to Brassicales. It was not because of the non-existence of ITS sequences of Brassicales in GenBank; as of this writing there are 5990 sequences of ITS locus belong to the members of Brassicales exist in the database. TrnL-F spacer sequences, both individually, as well as the consensus sequences generated for 14 of our ingroup isolates, retrieved Salvadora angustifolia (KC479309) as the closest hit with an E-value of 0 and
99.4\% identity, well within generally accepted conspecific threshold $(98.7 \%)[27,28]$. Particulars of top 10 hits were summarized in Table 3, and all 10 of them were from order Brassicales. Comparable results were obtained in discontinuous Mega BLAST as well (results not presented); with all top ten hits of ITS belonging to Sapindales, and that of $\operatorname{trnL}-F$ spacer belong to Brassicales.

\begin{tabular}{|l|l|l|l|}
\hline $\begin{array}{l}\text { S. } \\
\text { No. }\end{array}$ & Species & GenBank Accession & $\begin{array}{l}\text { Percent } \\
\text { Identity }\end{array}$ \\
\hline 1 & Arfeuillea arborescens & EU720461 & 79 \\
\hline 2 & Acer laurinum & AM113543 & 80 \\
\hline 3 & Acer laurinum & AM113542 & 79 \\
\hline 4 & Protium serratum & KJ503508 & 80 \\
\hline 5 & Protium cranipyrenum & KJ503531 & 80 \\
\hline 6 & Protium ravenii & KJ503448 & 80 \\
\hline 7 & Atalaya alata & EU720425 & 79 \\
\hline 8 & Protium glabrescens & KJ503444 & 79 \\
\hline 9 & Protium urophyllidium & AY375516 & 80 \\
\hline 10 & Acer laurinum & DQ366114 & 79 \\
\hline
\end{tabular}

Table 2: Particulars of top 10 BLASTN hits of consensus sequence of ITS region from Salvadora oleoides isolates from Punjab, India. All ten were from order Sapindales.

\begin{tabular}{|l|l|l|l|}
\hline S. No. & Species & $\begin{array}{l}\text { GenBank } \\
\text { Accession }\end{array}$ & $\begin{array}{l}\text { Percent } \\
\text { Identity }\end{array}$ \\
\hline 1 & Salvadora angustifolia & KC479309 & 99.4 \\
\hline 2 & Borthwickia trifoliata & JQ733128 & 87.7 \\
\hline 3 & Borthwickia trifoliate & JQ733129 & 87.7 \\
\hline 4 & Borthwickia trifoliata & JQ733127 & 87.7 \\
\hline 5 & Tovaria pendula & FJ212280 & 83.8 \\
\hline 6 & Tovaria pendula & AY122465 & 83.4 \\
\hline 7 & Pentadiplandra brazzeana & AY122463 & 83.0 \\
\hline 8 & Bretschneidera sinensis & JF448517 & 83.0 \\
\hline 9 & Moringa ovalifolia & JX091844 & 82.7 \\
\hline 10 & Moringa rivae & JX091846 & 82.7 \\
\hline
\end{tabular}

Table 3: Particulars of top 10 BLASTN hits of consensus sequence of trnL-F spacer region from Salvadora oleoides isolates from Punjab, India. All ten were from order Brassicales.

\section{Phylogeography}

Results of phylogeographic assessment using ITS and trnL-F spacer regions are presented as Figure 2. In summary, ITS phylogram resolved intraspecific clades better than $\operatorname{trn} L-F$ spacer phylogram. Intraspecific genetic diversity (within-group mean distance) for ITS dataset (0.020) was found to be higher than that of $\operatorname{trnL}-F$ spacer dataset $(0.003)$. Corrected (T92 model) pairwise distances of ITS dataset ranged 
Citation: Bast F, Kaur N (2017) Nuclear and Plastid DNA Sequence-based Molecular Phylogeography of Salvadora oleoides (Salvadoraceae) in Punjab, India Reveals Allopatric Speciation in Anthropogenic Islands Due to Agricultural Expansion. J Phylogenetics Evol Biol 5: 180. doi:10.4172/2329-9002.1000180

Page 5 of 7

between 0 , between isolates Jalandhar and Ludhiana, and 0.063 between isolates Zira and Talwandi Sabo. Corrected (JC69 model) pairwise distances of $\operatorname{trn} L-F$ dataset ranged between 0 , between isolates Moga and Zira, and 0.008 between isolates Barnala and Zira.

ITS phylogram resolved four clades. In general, geographically closer isolates clustered into distinct clades. The best-supported clade (Clade 1) consisted of isolates from Mukatsar and Talwandi Sabo, followed by a clade consisting of Abohar and Faridkot (Clade 4). The later clade (Clade 4) nested within a larger clade consisting of the majority of sampled isolates (Clade 3 ). Another, moderately supported, clade consisted of isolates from Kotkapura and Zira (Clade 2). Clades 1,2 and 3 formed a trichotomy, with each clade being sister to the rest two clades. trnL-F phylogram resolved only one clade (Clade 5) that consisted of isolates from Bathinda, Faridkot, and Taran Taaran. All other isolates occupied a basal position in a giant polytomy, perhaps indicating low phylogenetic signal for sufficient resolution. Interestingly, an accession of $S$. angustifolia (KC479309) clustered within this polytomy. The trnL-F phylogram broach few possibilities; either a cryptic speciation inside the range of parent population (as $S$. angustifolia clustered within the clade), or synonymy of $S$. oleoides and $S$. angustifolia (as the group consisting of these two taxa was polyphyletic). Considering clades in ITS phylogram as haplotype variants, respective geographical locations of these haplotypes are labeled in Figure 1.
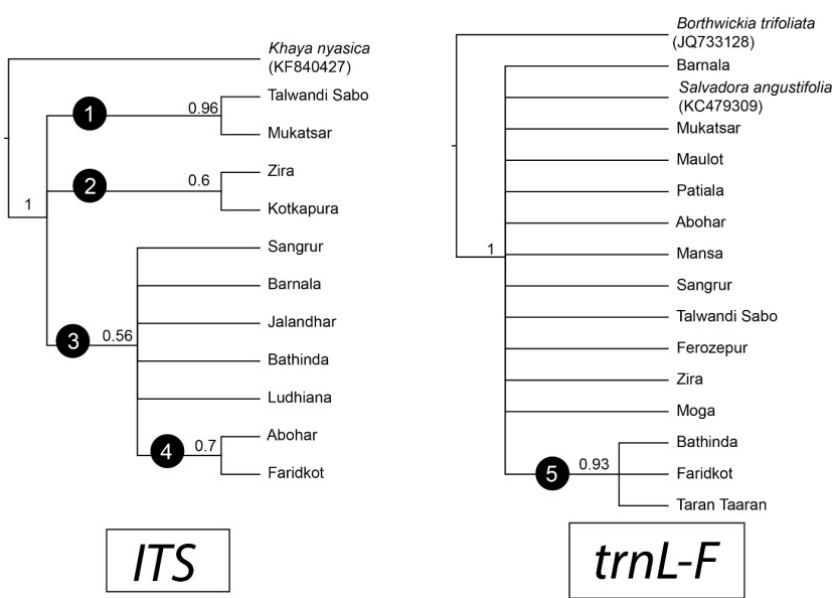

Figure 2: Bayesian Inference (BI) Molecular Phylogeny inferred from ITS (left) and trnL-F (right) sequences. The evolutionary history was inferred by using the Bayesian Inference method based on the JC69 (for ITS) and T92 (for trnL-F) models. For ITS tree, mean $\mathrm{LnL}=-1642.375$ and effective sample size $=4059.229$. For $\operatorname{trn} L$ $F$ tree, mean $\mathrm{LnL}=-1005.345$ and effective sample size $=3504.021$.

\section{Phylogenetic position of Salvadorales within Malvids}

Results of our ITS sequence-based phylogenetic assessment of the comparative position of family Salvadoraceae within malvids corroborated our earlier observation of the BLASTN affinity of this family with Sapindales (Figure 3). Salvadora clustered within the strongly supported monophyletic clade of Sapindales and occupied a position phylogenetically closer to family meliaceae. On the other hand, our trnL-F spacer-based phylogram clustered Salvadoraceae within Brassicales with strong bootstrap support (Figure 4).

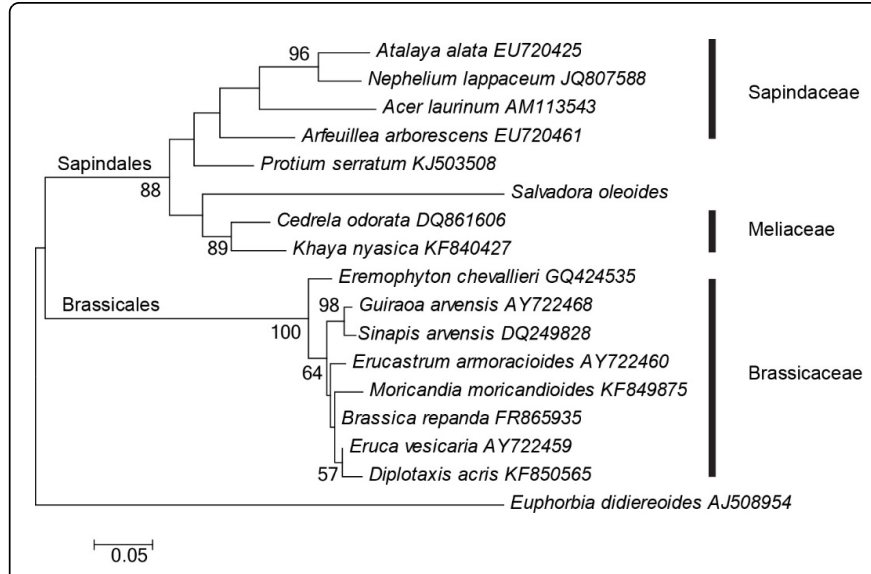

Figure 3: Maximum likelihood (ML) phylogram based on ITS1-5.8S-ITS2 sequences using $\mathrm{K} 2 \mathrm{P}+\mathrm{G}$ model of molecular evolution in MEGA phylogenetic framework. Numbers near nodes represent ML bootstrap proportion exceeding 50. $\mathrm{LnL}=-1860.2630$. Bootstrap proportions (500 replicates) exceeding 50 were shown near nodes. Scale bar is on the unit of average nucleotide substitutions per site. The analysis involved 17 nucleotide sequences. All positions with less than $95 \%$ site coverage were eliminated. That is, fewer than $5 \%$ alignment gaps, missing data, and ambiguous bases were allowed at any position. There were a total of 335 positions in the final dataset.

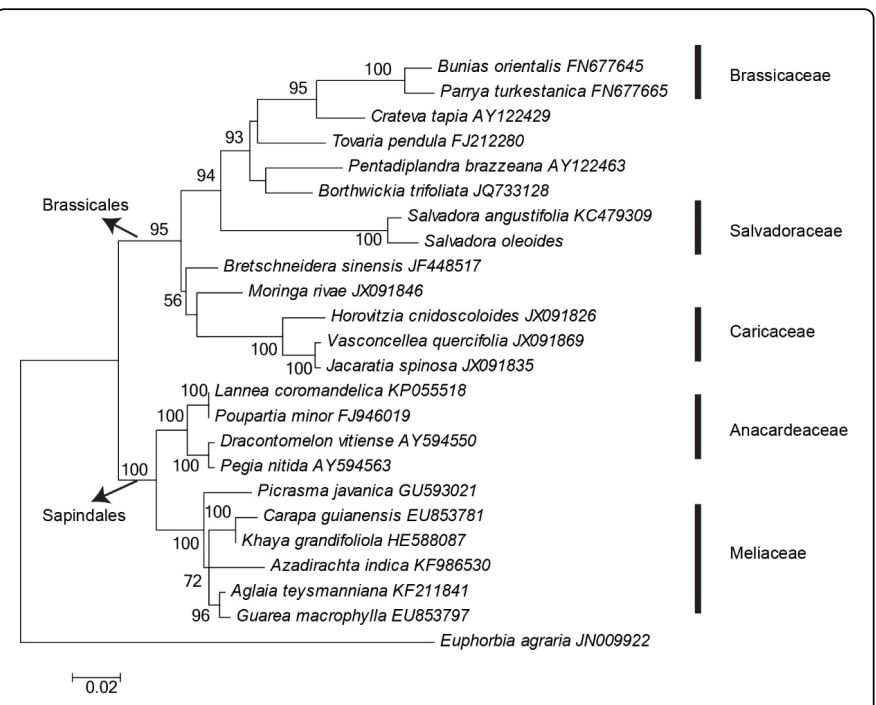

Figure 4: Maximum likelihood (ML) phylogram based on trnL-F sequences using $\mathrm{T} 92+\mathrm{G}$ model of molecular evolution in MEGA phylogenetic framework. Numbers near nodes represent ML bootstrap proportion exceeding 50. $\mathrm{LnL}=-2302.8388$. Bootstrap proportions (500 replicates) exceeding 50 were shown near nodes. Scale bar is on the unit of average nucleotide substitutions per site. The analysis involved 24 nucleotide sequences. All positions with less than $95 \%$ site coverage were eliminated. That is, fewer than $5 \%$ alignment gaps, missing data, and ambiguous bases were allowed at any position. There were a total of 445 positions in the final dataset. 
Citation: Bast F, Kaur N (2017) Nuclear and Plastid DNA Sequence-based Molecular Phylogeography of Salvadora oleoides (Salvadoraceae) in Punjab, India Reveals Allopatric Speciation in Anthropogenic Islands Due to Agricultural Expansion. J Phylogenetics Evol Biol 5: 180. doi:10.4172/2329-9002.1000180

Page 6 of 7

\section{Discussion}

This study generated DNA barcode data for Salvadora oleoides for the first time in the world. Comparing with $\operatorname{trn} L-F$, ITS locus exhibited more within-group distance, as well as resolved finer phylogeographic structures. It can be concluded that ITS is a useful locus for within species phylogeographic assessment in this species. Most probably this is due to differential evolutionary rates for these two loci; ITS- being an intron within the nucleoribosomal region- is more prone to mutations, while $\operatorname{trnL}-F$ being an intergenic spacer is more evolutionarily conserved. On the other hand, in phylogenetic analysis within malvids using ITS, a longer branch-length observed for the consensus sequence of our isolates suggest that it is a rapidly evolving Operational Taxonomic Unit with elevated substitution rates. Indeed, long stretch of insertions (22 nucleotides long) are observed for our consensus sequence near the end of ITS2 region, between sites 636 and 658 , in the ITS alignment. As the method we adopted to infer the phylogeny was Maximum Likelihood-which had been proven to be less prone to Long Branch Artifacts, it is likely that this disproportionately Long Branch length was not due to any artifacts. One likely explanation is allopatric speciation [29]. Within-group mean distance observed for our isolates in ITS dataset (0.02) is indeed the highest ever recorded among angiosperms. Given that the isolates are sampled from area spanning ca $23000 \mathrm{~km} 2$ with no apparent physical barriers between them, barriers in the form of anthropogenic islands due to habitat destruction could very well construe a vicariance mediator and likelihood for such a scenario of allopatric speciation is quite high. A word of caution in this conclusion is deemed necessary. While the current patterns of geographic differentiation may ultimately lead to long-term divergence and speciation, these might also be latest in several cycles of ephemeral patterns of genetic differentiation that this long-lived species have experienced.

Our phylogeographic assessment revealed the existence of five intraspecific clades of $S$. oleoides. Although the correlation between evolutionary distances and genetic distances were rather weakly negative (i.e., geographically close isolated had larger genetic distances between them, $R 2=0.0211$ ), geographically closely located isolates were part of distinct clades in our phylograms. This observation in turn suggests an evolutionary congruence across geographic space. As DNA barcode data for this species is non-existent in public sequence repositories prior to this study, we were unable to perform finer phylogeographic assessments, including its center of origin and dispersal routes. It can be nevertheless concluded that factors such as habitat destruction through agricultural expansion of plains might have forced the remaining population of this tree to isolated patches of thorn forest biotas analogous to an archipelago. Our analyses were insufficient to conclude whether vicariance phenomena or range expansion through geodispersal shaped the current patterns of its distribution. Separation of once contiguous area of species distribution, as observed in this study, does not warrant these endemic spots are related geologically. We can only infer that these biotas were once part of a continuous range and most probable explanation for the apparent vicariance is the anthropogenic agricultural expansion.

An important aspect of our trnL-F phylogram is that it clustered $S$. angustifolia within our geographical isolates of $S$. oleoides. In addition, the percent identity between the consensus sequence of $S$. oleoides and S. angustifolia, 99.4\%, was well within the intraspecific range commonly accepted for angiosperms. It can be inferred that these two species are conspecific. According to the principle of priority [30] the binomen $S$. oleoides (Decne, 1844) should be preferred over $S$. angustifolia (Turril, 1918).

The most surprising finding is the affinity of salvadoraceae in Sapindales as revealed by our phylogram based on ITS locus. In our knowledge, this is the first study that revealed such an affinity using molecular phylogeny. This finding corroborates an earlier morphology-based systematic scheme that grouped Salvadoraceae under Sapindales. However, as per our $\operatorname{Trn} L-F$ phylogram, Salvadoraceae is affiliated in Brassicales, as currently considered by the majority of angiosperm systematicists. The reason for this contrasting observation remains elusive; this might be related to the differential manner in which these two loci evolve along plant lineages. ITS, being a nuclear intron, are prone to recombination and follows biparental inheritance. $\operatorname{trn} L-F$, on the other hand, being an intergenic spacer in plastid genome, are not prone to recombination and follows the typical matrilineal pattern of inheritance. However, phylogeny based on $18 \mathrm{~S}$ locus, another nuclear region contiguous to the ITS intron, revealed affiliation of Salvadoraceae in Brassicales [4]. Our conflicting finding warrants need for further scrutiny of angiosperm phylogeny based on multi-local concatenated approach with integrated morphometric dataset, for having the total evidence (supermatrix [31]) at our disposal. In earlier molecular systematic analyzes as well as comparative analyzes based on floral anatomy [32] and seed anatomy [33], Salvadoraceae had been shown to be evolutionarily closely related with Bataceae and Koberliniaceae. Although we were really interested in this affinity, as well as relative phylogenetic positions of families Bataceae and Koberliniaceae within malvids, neither ITS nor trnL-F sequences from any of its members are currently available at GenBank. A few other observations in our phylogenetic analysis of malvids are deemed noteworthy. Our ITS phylogram revealed non-monophyly of family sapindaceae, with Acer, a member of aceraceae, clustered within the clade consisting otherwise of the members of sapindaceae. As per our trnL-F phylogram, affiliation of Picrasma, currently considered to be a member of family Picrasmaceae, within the family Meliaceae was obvious, as meliaceae+Picrasma had a strongly supported $(\mathrm{BP}=100)$ clade. Similarly, the genus Crateva, currently considered to be part of family cratevaceae, showed strong affinity $(\mathrm{BP}=95)$ to the family Brassicaceae.

This is the first DNA-sequence based phylogeographic assessment of Salvadora in the world. Sequence based phylogeographic assessment of tropical tree species is a relative rarity and in India, such investigations are almost non-existent. It is hopeful that the natural history of $S$. oleoides in Indian Subcontinent revealed in the present study would be beneficial for further, larger-scale phylogeographic assessment of this species for testing various hypotheses on geological, climatological and anthropogenic factors that might have shaped its current distribution. In addition, it is hopeful that our revelation of the affinity of Salvadoraceae to Sapindales would foster further, more detailed, "total evidence" assessment of malvids by molecular systematicists working on this field.

\section{Acknowledgements}

We thank Dr. Kenneth J. Sytsma, University of Wisconsin, Madison for helpful insights. We are thankful to Dr. Pankaj Bhardwaj, Ms. Pooja Rani and Ms. Sheetal Sharma for support with experimental works. We are also thankful for the Vice-chancellor, the Central University of Punjab for his support with respect to the execution of this research. The study was supported by grant-in-aid "Research Seed Money" scheme of the Central University of Punjab. 
Citation: Bast F, Kaur N (2017) Nuclear and Plastid DNA Sequence-based Molecular Phylogeography of Salvadora oleoides (Salvadoraceae) in Punjab, India Reveals Allopatric Speciation in Anthropogenic Islands Due to Agricultural Expansion. J Phylogenetics Evol Biol 5: 180. doi:10.4172/2329-9002.1000180

Page 7 of 7

\section{Author's Contributions}

FB conceived the topic, interpreted the data and drafted the manuscript. NK collected the samples and performed the experiments.

\section{Funding}

The study was funded by a grant from Research Seed Money programme of Central University of Punjab, India

\section{Conflict of Interest}

The authors declare that they have no conflict of interest.

\section{References}

1. Oldfield S, Lusty C, MacKinven A (1998) The world list of threatened trees. World Conservation Press, pp: 540-573.

2. Khan M, Shinwari ZK, Musharaf S (2011) Conservation and ecological characteristic of Trees in Tehsil Karak Pakistan. JBES 1: 155-164

3. Bremer B, Bremer K, Chase M, Fay M, Reveal J, et al. (2009) an update of the Angiosperm phylogeny group classification for the orders and families of flowering plants: APG III. Bot J Linn Soc 161: 105-121.

4. Rodman J, Soltis P, Soltis D, Sytsma K, Karol K (1998) Parallel evolution of glucosinolate biosynthesis inferred from congruent nuclear and plastid gene phylogenies. Am J Bot 85: 997-997.

5. Yadav J, Saini S, Kalia A, Dangi A (2008) Hypoglycemic and hypolipidemic activity of ethanolic extract of Salvadora oleoides in normal and alloxan-induced diabetic rats. Indian J Pharmacol 40: 23-27.

6. Kumar S, Dhankhar S, Arya VP, Yadav S, Yadav J (2012) Antimicrobial activity of Salvadora oleoides Decne. against some microorganisms. J Med Plants Res 6: 2754-2760.

7. Quéméré E, Hibert F, Miquel C, Lhuillier E, Rasolondraibe E, et al.(2013) A DNA metabarcoding study of a primate dietary diversity and plasticity across its entire fragmented range. PloS ONE 8: 1-11.

8. Savolainen V, Fay MF, Albach DC, Backlund A, van der Bank M, et al. (2000) Phylogeny of the eudicots: a nearly complete familial analysis based on rbcL gene sequences. Kew Bull 55: 257-309.

9. Yadav J, Kumar S, Yadav M, Kadyan S, Yadav S (2014) Assessment of genetic diversity using RAPD marker among different accessions of Salvadora oleoides of North-West India. Biores Bull 1: 1-6.

10. Saini S, Yadav J (2013) Genetic variation in natural populations of Salvadora oleoides: An important medicinal plant that needs conservation. Asian J Plant Sci Res 3: 20-27.

11. Croizat L (1964) Space, Time, and Form, the Biological Synthesis. Published by the author, Caracas

12. Patriat P, Achache J (1984) India-Eurasia collision chronology has implications for crustal shortening and driving mechanism of plates. Nature 311: 615-621.

13. Franzke A, Lysak MA, Al-Shehbaz IA, Koch MA, Mummenhoff K (2011) Cabbage family affairs: the evolutionary history of Brassicaceae. Trends in Plant Science 16: 108-116.

14. Khan M, Hussain F, Musharaf S (2013) Conservation status of trees in Tehsil Takht-e-Nasratti, Karak Pakistan. Afr J Plant Sci 7: 201-207.
15. Holsinger KE, Gottlieb L (1991) Conservation of rare and endangered plants: principles and prospects. Genetics and conservation of rare plants. Oxford University Press, NY, USA pp: 195-208.

16. Engler A, Diels L (1936) A. Engler's Syllabus der Pflanzenfamilien.

17. Dahlgren G (1989) an updated angiosperm classification. Bot J Linn Soc 100: 197-203.

18. Goldberg A (1986) Classification, evolution, and phylogeny of the families of Dicotyledons Smithsonian contributions to botany. Smithsonian Institution Press, Washington : Smithsonian Institution Press.

19. Takhtajan AL (1997) Diversity and classification of flowering plants. Columbia University Press.

20. Thorne RF (1992) An updated phylogenetic classification of the flowering plants. Aliso 13: 365-389.

21. Kress WJ, Wurdack KJ, Zimmer EA, Weigt LA, Janzen DH (2005) Use of DNA barcodes to identify flowering plants. Proc Natl Acad Sci USA 102: 8369-8374

22. White TJ, Bruns T, Lee S, Taylor J (1990) Amplification and direct sequencing of fungal ribosomal RNA genes for phylogenetics, vol 18 . PCR protocols: a guide to methods and applications. Academic Press, Waltham, Massachusetts pp: 315-322.

23. Poeaim A, Poeaim S, Soytong K, Krajangvuthi T (2012) Genetic diversity of Ficus carica L. based on non-coding regions of chloroplast DNA. Paper Presented at The 8th International Symposium on Biocontrol and Biotechnology.

24. Baraket G, Olfa S, Khaled C, Messaoud M, Mohamed M, et al. (2008) Chloroplast DNA analysis in Tunisian fig cultivars (Ficus carica L.) Sequence variations of the trnL-trnF intergenic spacer. Biochem Syst Ecol 36: 828-835.

25. Bast F, Rani P, Meenal D (2014) Chloroplast DNA phylogeography of Holy Basil (Ocimum tenuiflorum) in Indian subcontinent. Sci World J 2014.

26. Bast F (2013) Sequence similarity search, multiple sequence alignment, model selection, distance matrix and phylogeny reconstruction. Nature Protocol Exchange.

27. Schloss PD, Handelsman J (2004) Status of the microbial census. Microbiol Mol Biol Rev 68: 686-691.

28. Hoskin CJ, Higgie M, McDonald KR, Moritz C (2005) Reinforcement drives rapid allopatric speciation. Nature 437: 1353-1356.

29. McNeill J (2012) International Code of Nomenclature for algae, fungi and plants (Melbourne Code). Koeltz Scientific Books.

30. Sanderson MJ, Purvis A, Henze C (1998) Phylogenetic supertrees: Assembling the trees of life. Trends Ecol Evol 13: 105-109.

31. De Craene LR, Wanntorp L (2009) Floral development and anatomy of Salvadoraceae. Ann Bot 104: 913-923.

32. Tobe H, Raven PH (2012) Seed morphology and anatomy in Salvadoraceae (Brassicales): Systematic and evolutionary implications. APG 63: 1-9.

33. Khan A (1996) Appraisal of ethno-ecological incentives to promote conservation of Salvadora oleoides Decne: The case for creating a resource area. Biol Conserv 75: 187-190.
This article was originally published in a special issue, entitled: "Trends of Evolutionary Biology \& Molecular Phylogenetics", Edited by Xiong Momiao 